\title{
Proceeding
}

Supplementary Issue: Summer Conferences of Sports Science. Costa Blanca Sports Science Events, 20-21 September 2019.

Alicante, Spain.

\section{Nutrition program effect on soccer players}

\author{
FRANCESCO PERROTTA
}

University of Ljubljana, Slovenia

\begin{abstract}
This paper is designed to help coaches and educators in their mission, reporting different knowledge based, as well as on the most classic consensus theories, on the most up-to- date scientific acquisitions about the most appropriate way to feed and organize their nutrition before, during and after a part or a training session. The text will be deliberately concise, but the bibliographic sources added as reference, portrayed in the international scientific literature, will constitute an ulterior study opportunity for those wishing to deepen each single topic. Keywords: Expertise; Soccer; Nutrition advise; Vitamins.
\end{abstract}

Cite this article as:

Perrotta, F. (2019). Nutrition program effect on soccer players. Journal of Human Sport and Exercise, 14(5proc), S1824-S1828. doi:https://doi.org/10.14198//hse.2019.14.Proc5.01

Corresponding author. University of Ljubljana, Slovenly. https://orcid.org/0000-0003-1031-1729

E-mail: francescoperrotta@msn.com

Supplementary Issue: Summer Conferences of Sports Science. Costa Blanca Sports Science Events, 20-21 September 2019. Alicante, Spain.

JOURNAL OF HUMAN SPORT \& EXERCISE ISSN 1988-5202

(c) Faculty of Education. University of Alicante

doi:10.14198/jhse.2019.14.Proc5.01

S1824 | 2019|Proc5 | VOLUME 14

C 2019 University of Alicante 


\section{INTRODUCTION}

This paper is designed to help coaches and educators in their mission, reporting different knowledge based, as well as on the most classic consensus theories, on the most up-to- date scientific acquisitions about the most appropriate way to feed and organize their nutrition before, during and after a part or a training session.

The text will be deliberately concise, but the bibliographic sources added as reference, portrayed in the international scientific literature, will constitute an ulterior study opportunity for those wishing to deepen each single topic.

\section{METHODS}

Why should football pay so much attention to the theme of food? Every coach knows that there is no player, from the great professional to the last of the amateurs, who does not have the desire to improve his competitive performances.

There are other factors that can determine the goodness of the performance in a football game, or even simply in a training session. Among these, it is undoubtedly to insert a correct diet. In fact, nutrition provides the player with all the elements necessary to sustain the energy required for sport. To avoid misunderstandings, it is opportune to state immediately that there are no "prodigious" foods, which improve athletic performance for themselves: this manual intends to explain how the footballer's nutrition, in order to be effective, must first supply all the reserves of " fuelled "necessary for the machine-man.

\section{RESULTS}

Entering the specific activity of sports, the energy demands of football will be described, and the differences between the different roles in the field and the different categories of amateur players.

The effect of the climatic conditions on the energy expenditure will therefore be mentioned. Moreover, it will be the body composition of the player, with practical rules for the evaluation of the same in athletes, and especially in children in growth.

Finally, the valence of ca will be discussed as an excellent complement to energy consumption in overweight organisms, provided it is associated with the necessary dietary reorganization.

\section{DISCUSSION \& CONCLUSIONS}

After the analysis of some nutritional facts in football and in sport in general, the nutritional goals in amateur football will be explained with indications, as far as possible practical, to face the organization of food in the particular situations typical of this sport, from the student, to the worker, to the child, to the Women's Football.

It is in fact important to deal with the issue of the actual needs and timing of caloric supply for the amateur footballer, because this can allow the athlete to not deplete the energy supply (a practice that may cause a drop in performance and expose the body to the risks of insufficient caloric supply) and on the other not to store too much energy (instead provoking increase in body weight and fat deposits, with all the risks that this entails for health, especially long term). 
This basically means maintaining that harmonic equilibrium between "entrain" and "exits" of energy from our organism that will allow us to maintain our weight, that is of the mass and the body composition, ideal for maintaining a healthy state of health. finally, the chapter will propose some nutritional indications for the interval of the match and for the post-game / training recovery.

\section{Hydration strategies}

In this chapter will be addressed the "water" demands of calcium, the possible negative effects of dehydration and water intake strategies. In fact, water is the first substance to be reintegrated during a physical activity. The possible roles of sports drinks will also be reviewed. finally, a special mention will be given to some drinks of common use, especially among the younger ones, such as sodas, alcohol, tea, coffee and milk.

\section{Integration}

Vitamins

Many vitamins are important factors in energy metabolism, which are essential for the player's activity. However, in a normal varied diet their needs, also for the needs of physical activity, are generally well satisfied.

Function of vitamins: Metabolic diseases and influence different physiological processes potentially linked to sports performance in particular, B vitamins are involved in the metabolic processes of carbohydrate oxidation and lipids during exercise and are important for the formation of haemoglobin, a fundamental protein for the transport of oxygen in the blood up to the muscular level.

Vitamin deficiencies: It is akin to a viatical carapace to improve physical performance (e.g. the intake for 4 weeks of $1 / 3$ of the recommended daily dose of B1, B2, B6 and vitamin C causes a significant decrease in the maximum oxygen consumption). However, most studies confirm that the vitamin intake in the common Western diets allows to cover abundantly the recommended daily dose. in general, vitamin supplements do not therefore appear necessary for players (including children) who follow a varied and well-balanced diet. The use of vitamin supplements can therefore be recommended only after having ascertained clinically an effective state of one or more vitamins.

Many minerals are also essential in energy processes and do not normally remain in a sufficiently varied diet. The only exception could be iron, especially in females, but its possible administration should be evaluated by the doctor. Lactoferrin could be helpful in iron supplementation.

Importance of minerals: Imitations of fundamentals in a lot of processing metabolic. They intervene in muscle contraction, in oxygen transport, in the balance of the acid-base balance of blood, in the functioning of some important enzymes and in different functions of the immune system. An optimal quantity of minerals therefore allows the proper functioning of all energy metabolic processes, which are also of fundamental importance for sports performance. A lack of minerals also has a negative influence on health. However, in a sufficiently varied and balanced diet the mineral intake is absolutely fulfilled, and there is therefore no need for integration in most cases.

The problem of iron : It is in fact one of the most important minerals for those who practice sport (it is one of the components of haemoglobin and myoglobin, proteins essential for the transport of oxygen to the tissues, and is present in many enzymes at the level of muscle cells) and - as said - the recommended intake is 12$16 \mathrm{mg}$ / day. It has been shown that the development of iron deficiency anaemia (called "sideropenic") is higher in athletes than in sedentary individuals. The causes for iron deficiency are small gastrointestinal 
losses of blood, profuse losses in sweat and, in women, menstrual losses. As already mentioned, it is a good idea to proceed with the integration of the iron under a medical prescription, and if this becomes necessary.

Lactoferrin: Can bind the iron molecule. It favours the homeostasis of the iron itself, most likely facilitating the intestinal absorption of this element and its deposit, especially at the level of the liver. In this sense, lactoferrin has proved to be able, according to the results of some recent studies, to provide an effective prevention against the anaemia of the athlete, especially female. Lactoferrin is also known for its anti-inflammatory and immunomodulatory properties, thus contributing to the strengthening of the immune system and the prevention of many infections. recently, it has also been approved by the European Food Safety Authority, which has recognized the validity of scientific studies to support its use as an immunomodulatory agent.

\section{Probiotics}

Probiotics are food supplements containing live microorganisms, which have a beneficial effect on intestinal bacterial flora and immune function.

Lactobacilli and bifid bacteria are among the probiotics currently most commercialized and consumed. Their action consists in modifying the intestinal bacterial flora, to reduce the presence of bacterial species that are harmful to the organism by increasing the beneficial ones. Besides having positive effects on digestion.

Finally, soccer players should be made aware of the impact of nutrition on the recovery process after exercise. The main targets for recovery nutrition are refilling carbohydrate stores and maximizing the muscle protein synthesis by providing enough protein at appropriate intervals. Intake of fat and fluid is unlikely to be a limiting factor in the restoration of exercise capacity but can play a permissive role. Bioactive food ingredients can have a modulating role in the inflammatory process, thereby speeding recovery. However, many questions remain. The use of "bio actives" should be carefully considered, with the possibility of doing more harm than good. Real food can be used to achieve recovery goals, but players' diets are often supplemented with specific products due to ease and practicalities. Practical issues such as total recovery time until the next match, diet quality and individual energy intake "budget" should be considered when planning an individualised recovery strategy.

\section{REFERENCES}

Conejos C., Giner A., Mañes J., Soriano J.M. Energy and nutritional intakes in training days of soccer players according to their playing positions. Arch. Med. Deporte. 2011.

Iglesias-Gutiérrez E., García-Rovés P.M., Rodríguez C., Braga S., García-Zapico P., Patterson A.M. Food habits and nutritional status assessment of adolescent soccer players. A necessary and accurate approach. Can. J. Appl. Physiol. 2005. https://doi.org/10.1139/h05-102

Lemon P.W.R. Protein requirements of soccer. J. Sports Sci. 1994.

Mohr M., Krustrup P., Bangsbo J. Match performance of high-standard soccer players with special reference to development of fatigue. J. Sports Sci. 2003. https://doi.org/10.1080/0264041031000071182

Perrotta, F. Dietetica e nutrizione nella mentalità sportiva. Una ricerca scientifica e metodologica per migliorare il proprio stile di vita, Editore: Edizioni Goliardiche, 2007, EAN: 9788878730465.

Ruiz F., Irazusta A., Gil S., Irazusta J., Casis L., Gil J. Nutritional intake in soccer players of different ages. J. Sports Sci. 2005. https://doi.org/10.1080/02640410410001730160 
Sporis G., Jukic I., Ostojic S.M., Milanovic D. Fitness profiling in soccer: Physical and physiologic characteristics of elite players. J. Strength Cond. Res. 2009. https://doi.org/10.1519/jsc.0b013e3181b3e141

Svensson M., Drust B. Testing soccer players. J. Sports Sci. 2005. https://doi.org/10.1080/02640410400021294 